\title{
Ecological Distribution Conflicts and the Vocabulary of
}

\section{Environmental Justice}

Joan Martinez-Alier **

\begin{abstract}
There is a fundamental clash between economy and the environment due to the growing social metabolism of industrial economies. Energy cannot be recycled. Therefore, the energy from the fossil fuels is used only once, and new supplies of coal, oil, and gas must be obtained from the "commodity extraction frontiers". Similarly, materials are recycled only in part, and therefore, even an economy that would not grow would need fresh supplies of iron ore, bauxite, copper, and paper pulp. The industrial economy is entropic. Meanwhile, permanent "funds" such as aquifers, forests, and fisheries are overexploited, the fertility of the soil is jeopardized and biodiversity is depleted. Thus, the changing social metabolism of industrial economies (including waste disposal such as the excessive production of carbon dioxide) gives rise to growing numbers of ecological distribution conflicts that sometimes overlap with other social conflicts on class, ethnicity or indigenous identity, gender, caste, or territorial rights. The term Ecological Distribution Conflicts (EDC) was coined to describe social conflicts born from the unfair access to natural resources and the unjust burdens of pollution. Such conflicts give birth to movements of resistance, to the point that we can speak already of a global movement for Environmental Justice.
\end{abstract}

\footnotetext{
* Professor of Economics and Economic History and ICTA researcher, at the Universitat Autonoma de Barcelona, Barcelona, Spain 


\section{Introduction}

The increasing number of ecological distribution conflicts around the world is ultimately caused by the changing metabolism of the economy in terms of growing flows of energy and materials. "Ecological distribution conflicts" (Martinez-Alier, 1995; Martinez-Alier \& O’Connor, 1996) is a term for environmental injustices that comes from ecological economics. For instance, a factory may be polluting the river (which belongs to nobody or belongs to a community that manages the river — as studied by Ostrom (1990) and her school). This is not a damage valued in the market. The same happens with climate change, causing perhaps sea level rise in some Pacific islands or in Kuna islands in Panama or in the Sunderbans. More than market failures (a terminology that implies that such externalities could be valued in money terms and internalized into the price system) these are "costshifting successes" (Kapp, 1950; Gerber, 2016) which oftentimes lead to complaints from those bearing them. If such complaints were effective (which is not the rule), some activities could be banned, or, if we accept economic commensuration and reject incommensurability of values (Martinez-Alier et al. 1998), "equivalent" eco-compensation mechanisms could be introduced. The economy would change accordingly.

The term "ecological distribution conflicts" has been used since 1995 to describe social conflicts born from the unfair access to natural resources and the unjust burdens of pollution. Environmental gains and losses are distributed in a way that causes such conflicts. While the term "economic distribution conflicts" in political economy describes conflicts between capital and labour (profits versus salaries), or conflicts on prices between sellers and buyers of commodities, or conflicts on the interest rate to be paid by debtors to creditors, the term "ecological distribution conflicts" in political ecology stresses the idea that the unequal or unfair distribution of environmental goods and bads is not always coterminous with economic distribution. 
Such ecological distribution conflicts were perceived in terms of persistent injustices towards "people of color" in the United States giving rise to a social movement in the 1980s when the words "environmental justice" (EJ) began to be used in struggles against the disproportionate dumping of toxic waste in urban or periurban African-American areas. EJ offers a powerful lens to make sense of many struggles over the negative impacts that the changing metabolism imposes on human livelihoods and nature conservation worldwide (Gottlieb 2005). As early as in 1991, at the "People of Color Environmental Leadership Summit" in Washington DC ties were forged so as "to begin to build a national and international movement of all peoples of color to fight the destruction and taking of our lands and communities" as the declaration states. The principles developed at this Summit spoke to the world, and not to a minority. Participants wanted to restablish humans' spiritual interdependence with the sacredness of our Mother Earth; to respect and celebrate each of our cultures, languages and beliefs about the natural world and our roles in healing ourselves; to ensure EJ and promote economic alternatives which would contribute to the development of environmentally safe livelihoods; and to secure political, economic, and cultural liberation denied for five centuries of colonization and oppression, resulting in the poisoning of communities and land and the genocide of peoples.

Conceptually "environmentalism of the poor" is related to the EJ movement applied to rural and indigenous populations in India and Latin America. It was introduced by academics and also by activists like Anil Agarwal and Sunita Narain of the Centre for Science and Environment (CSE) in India in the late 1980s and Hugo Blanco in Peru and early 1990s respectively. Since the mid-1990s the explicit connection between the two movements- EJ in the United States and the environmentalism of the poor in Latin America, Africa, and Asia was established both in theory and practice (Martinez-Alier, 1997; Guha and Martinez-Alier 
1997, 1999). In the mid-1990s, classical books analyzing movements against dams (McCully 1996) and tree plantations (Carrere and Lohman 1996) were published by activists while Leonardo Boff's Cry of the Earth, Cry of the Poor (1995) established the connections between poverty and environmental complaints. Boff is is a Brazilian "Liberation theologist" whose work has been fully vindicated in Pope Francis' encyclical Laudato si of 2015. The deaths of Chico Mendes (1988) fighting deforestation in Brazil, Ken Saro-Wiwa and his Ogoni comrades in the Niger Delta (1995) fighting oil extraction and gas flaring by Shell, and hundreds of others down to Berta Cáceres in Honduras (2016) fighting the Agua Zarca hydroelectric dam and grandmother Gloria Capitan (2016) in the Philippines struggling against coal stockpiling in Mariveles, plus many other deaths of environmental defenders (as listed by Global Witness, and also in the EJAtlas), have cemented the links between EJ and the environmentalism of the poor.

\section{The vocabulary of environmental justice}

Since the 1980s and 1990s the global EJ movement developed a set of concepts and campaign slogans to describe and intervene in ecological distribution conflicts. Critical to the development of global EJ networks and activist movements has been the conceptual language that has arisen from particular conflicts such as those collected in the EJAtlas (www.ejatlas.org). We present here a set of concepts with origins outside academia and which are used by the global EJ movement (Martinez-Alier et al. 2014; Sikor and Newell 2014). Many of them come from Latin America and India. Enviromental Justice Organisations (EJOs) have produced not only a series of powerful concepts but they also link them to practice through what Charles Tilly called "repertoires of collective action" in his study of other social movements (Martinez-Alier et al. 2014; Tilly and Tilly 1981). Short definitions and the dates of origin of such concepts are provided in Table 1 . This does not 
come only from the knowledge acquired through the EJOLT project (2011-15) and the

compilation of the EJAtlas but also from previous research together with activists over many

years (Martinez-Alier 2002; Healy et al. 2012).

\begin{tabular}{|c|c|c|}
\hline Concept & $\begin{array}{l}\text { EJOs ar other organizations } \\
\text { promoting it }\end{array}$ & SHORT DESCRIPTION \\
\hline $\begin{array}{l}\text { Environmental } \\
\text { Justice (EJ) }\end{array}$ & $\begin{array}{l}\text { USA Civil Rights } \\
\text { Movement, North } \\
\text { Carolina } 1982 \text { against } \\
\text { environmental injustices } \\
\text { (Bullard } 1990 ; 1999) .\end{array}$ & $\begin{array}{l}\text { "People of color" and low-income populations } \\
\text { suffer disproportionate harm from waste sites, } \\
\text { refineries and incinerators, transport } \\
\text { infrastructures. }\end{array}$ \\
\hline $\begin{array}{l}\text { Environmental } \\
\text { racism }\end{array}$ & $\begin{array}{l}\text { Rev Benjamin Chavis, } \\
1982\end{array}$ & $\begin{array}{l}\text { The fight for EJ, against pollution in Black, } \\
\text { Hispanic, Indigenous areas, was seen as a fight } \\
\text { against environmental racism. }\end{array}$ \\
\hline Ecological debt & $\begin{array}{l}\text { Instituto Ecología } \\
\text { Política, Chile, 1992, } \\
\text { Acción Ecológica } 1997\end{array}$ & $\begin{array}{l}\text { Rich countries' liability for resource plunder } \\
\text { and disproportionate use of space for waste } \\
\text { dumping (e.g. GHG). }\end{array}$ \\
\hline $\begin{array}{l}\text { Popular } \\
\text { epidemiology }\end{array}$ & Brown, P. , 1992, 1997 & $\begin{array}{l}\text { "Lay" local knowledge of illnesses from } \\
\text { pollution may be more valid than official } \\
\text { knowledge (sometimes absent). }\end{array}$ \\
\hline $\begin{array}{l}\text { Environmentalism of } \\
\text { the poor }\end{array}$ & $\begin{array}{l}\text { A.Agarwal/S. Narain } \\
\text { (CSE, Delhi) c. } 1989\end{array}$ & $\begin{array}{l}\text { Struggles by poor/ indigenous peoples against } \\
\text { deforestation, dams, mining...; ; proactive } \\
\text { collective projects for water harvesting, and } \\
\text { forest conservation }\end{array}$ \\
\hline Food sovereignty & Via Campesina, c. 1993 & $\begin{array}{l}\text { People's right to healthy, culturally appropriate, } \\
\text { sustainably produced food. Right to define own } \\
\text { food and agriculture systems. }\end{array}$ \\
\hline Biopiracy & $\begin{array}{l}\text { RAFI (Pat Mooney) } \\
\text { 1993, popularized by } \\
\text { Vandana Shiva }\end{array}$ & $\begin{array}{l}\text { Appropriation of genetic resources (in } \\
\text { medicinal or agricultural plants) without } \\
\text { recognition of knowledge and property rights } \\
\text { of indigenous peoples }\end{array}$ \\
\hline Climate justice & $\begin{array}{l}\text { CES (Delhi), 1991, } \\
\text { Durban Alliance, } \\
\text { CorpWatch 1999-2002 }\end{array}$ & $\begin{array}{l}\text { Radically reduce excessive per capita emissions } \\
\text { of carbon dioxide and other GHG. "Subsistence } \\
\text { emissions vs. luxury emissions", }\end{array}$ \\
\hline $\begin{array}{l}\text { Water justice, hydric } \\
\text { justice }\end{array}$ & $\begin{array}{l}\text { Rutgerd Boelens, EJOs in } \\
\text { Latin America (e.g. } \\
\text { CENSAT). } 2011 .\end{array}$ & $\begin{array}{l}\text { Water should not run towards money, or } \\
\text { towards power. It should go to those needing it } \\
\text { for livelihood. }\end{array}$ \\
\hline Water as human right & $\begin{array}{l}\text { Pablo Solon (Bolivian } \\
\text { envoy to UN), Maud } \\
\text { Barlow (Council of } \\
\text { Canadians), } 2001\end{array}$ & $\begin{array}{l}\text { Human Right to Water recognized at UN level } \\
\text { in } 2011 \text {, as an independent human right. }\end{array}$ \\
\hline "Green Deserts" & $\begin{array}{l}\text { Brazil, network against } \\
\text { eucalyptus plantations, } \\
\text { Rede Alerta contra o } \\
\text { Deserto Verde, } 1999\end{array}$ & $\begin{array}{l}\text { Brazilian local term for eucalyptus plantations, } \\
\text { used by networked CSO and communities, also } \\
\text { by researchers and activists for any tree } \\
\text { plantation. }\end{array}$ \\
\hline $\begin{array}{l}\text { Tree Plantations are } \\
\text { not Forests }\end{array}$ & $\begin{array}{l}\text { Pulping the South, } 1996 \\
\text { by R. Carrere, L. } \\
\text { Lohman, World } \\
\text { Rainforest Movement }\end{array}$ & $\begin{array}{l}\text { The WRM collects and spreads information on } \\
\text { tree plantation conflicts. It proposes a change in } \\
\text { the FAO definition of forest, to exclude tree } \\
\text { monocultures. }\end{array}$ \\
\hline Land grabbing & $\begin{array}{l}\text { GRAIN ( small pro- } \\
\text { peasant EJO), } 2008\end{array}$ & $\begin{array}{l}\text { The wave of land acquisitions in Southern } \\
\text { countries for plantations for exports, leading to } \\
\text { first statistics on land-grabbing }\end{array}$ \\
\hline Resource caps & $\begin{array}{l}\text { Resource Cap Coalition, } \\
\text { RCC Europe, c. } 2010\end{array}$ & $\begin{array}{l}\text { It advocates reduction in global resource use } \\
\text { and in poverty. It calls for a European energy } \\
\text { quota scheme and the ratification of the Rimini }\end{array}$ \\
\hline
\end{tabular}




\begin{tabular}{|c|c|c|}
\hline & & protocol. \\
\hline $\begin{array}{l}\text { To Ogonize / } \\
\text { Yasunize }\end{array}$ & $\begin{array}{l}\text { ERA Nigeria, Acción } \\
\text { Ecológica, Oilwatch, } \\
\text { 1997-2007 }\end{array}$ & $\begin{array}{l}\text { Leave oil in the soil to prevent damage to } \\
\text { human rights and biodiversity, and against } \\
\text { climate change. Adopted by anti shale gas } \\
\text { fracking, tar sands and open cast coal mining } \\
\text { movements. }\end{array}$ \\
\hline Rights of Nature & $\begin{array}{l}\text { Ecuador, Constitutional } \\
\text { Assembly, } 2008\end{array}$ & $\begin{array}{l}\text { In Constitution of Ecuador 2008, art 71, pushed } \\
\text { by Acción Ecológica and Alberto Acosta. } \\
\text { Actionable in court. }\end{array}$ \\
\hline $\begin{array}{l}\text { Corporate } \\
\text { accountability }\end{array}$ & $\begin{array}{l}\text { Friends of the Earth } \\
\text { International, 1992-2002 }\end{array}$ & $\begin{array}{l}\text { At UN Johannesburg summit, FoE proposed the } \\
\text { adoption of a Corporate Accountability } \\
\text { Convention, against lukewarm CSR principles. }\end{array}$ \\
\hline $\begin{array}{l}\text { "Critical mass", } \\
\text { cyclists rights }\end{array}$ & $\begin{array}{l}\text { San Francisco } 1992 \\
\text { (Chris Carlsson) }\end{array}$ & $\begin{array}{l}\text { International movement reclaiming the streets, } \\
\text { cyclists marching to impose cyclists rights. }\end{array}$ \\
\hline $\begin{array}{l}\text { Urban waste } \\
\text { recyclers movements }\end{array}$ & $\begin{array}{l}\text { c. } 2005 \text {, GAIA against } \\
\text { incineration and "energy } \\
\text { valorization" of urban } \\
\text { waste. }\end{array}$ & $\begin{array}{l}\text { Unions or cooperatives of urban waste } \\
\text { gatherers, with their positive environmental } \\
\text { impact, including climate change (movements } \\
\text { in Delhi, Pune, Bogota). }\end{array}$ \\
\hline $\begin{array}{l}\text { Urban "guerrilla food } \\
\text { gardening" }\end{array}$ & $\begin{array}{l}\text { c. } 2000, \text { started by "food } \\
\text { justice" networks }\end{array}$ & $\begin{array}{l}\text { Vacant lot food growing, permaculture, } \\
\text { community gardening movements in cities } \\
\text { around the world. }\end{array}$ \\
\hline $\begin{array}{l}\text { Toxic colonialism, } \\
\text { toxic imperialism }\end{array}$ & $\begin{array}{l}\text { BAN, Basel Action } \\
\text { Network, c. } 2000\end{array}$ & $\begin{array}{l}\text { Fighting the long-distance export of waste from } \\
\text { rich to poor countries, forbidden by the Basel } \\
\text { Treaty. E.g. ship-breaking in South Asia, } \\
\text { chemical residues or nuclear waste, e- waste. }\end{array}$ \\
\hline Post-extractivism & $\begin{array}{l}\text { Latin America, 2007, } \\
\text { E. Gudynas (CLAES), A. } \\
\text { Acosta, Maristella } \\
\text { Svampa }\end{array}$ & $\begin{array}{l}\text { Against the reprimarization of LA economies. } \\
\text { Transition to a sustainable economy based on } \\
\text { solar energy and renewable materials. Impose } \\
\text { quotas and taxes on raw materials exports. }\end{array}$ \\
\hline $\begin{array}{l}\text { Buen Vivir, Sumak } \\
\text { Kawsay }\end{array}$ & $\begin{array}{l}\text { Ecuador and Bolivia } \\
2008\end{array}$ & $\begin{array}{l}\text { Adopted in Constitutions of both countries, } \\
\text { inspired by indigenous traditions and by the } \\
\text { "post-development" approach. }\end{array}$ \\
\hline $\begin{array}{l}\text { Indigenous territorial } \\
\text { rights, and prior } \\
\text { consultations }\end{array}$ & $\begin{array}{l}\text { Convention } 169 \text { of ILO, } \\
1989 ; \text { adivasi forest } \\
\text { rights in India... }\end{array}$ & $\begin{array}{l}\text { In conflicts on mining, oil exploitation, dams... } \\
\text { communities ask for applying legislation } \\
\text { defending indigenous rights.. }\end{array}$ \\
\hline "Sand mafias" & $\begin{array}{l}\text { Name given c. } 2005 \text { by } \\
\text { environmental } \\
\text { movement, journalists. }\end{array}$ & $\begin{array}{l}\text { The illegal "mining" of sand and gravel in India } \\
\text { in many rivers, driven by the growing building } \\
\text { and public works industry. }\end{array}$ \\
\hline "Cancer villages" & $\begin{array}{l}\text { In China, popular name } \\
\text { adopted by academics, } \\
\text { officials (Lora-Wainright, } \\
\text { 2013) }\end{array}$ & $\begin{array}{l}\text { Rural villages where industry has caused } \\
\text { pollution (e.g. heavy metals), where lay } \\
\text { knowledge of illness is relevant, and subdued } \\
\text { protests take place. }\end{array}$ \\
\hline
\end{tabular}

There are concepts of academic origin (such as "working class environmentalism" [Barca, 2012], "ecologically unequal trade" [Hornborg, 1998] or "ecological footprint") that are also used or could be used by the global EJ movement. Here we focus on concepts of nonacademic origin. The first concept in the list is "environmental justice," born in the United States in struggles against waste dumping in North Carolina in 1982, as mentioned above. Activist authors such as sociologist Robert Bullard but also civil rights activists with no 
academic affiliation and members of Christian churches, saw themselves as militants of EJ (Bullard1999; Bryant and Mohai1992; Agyeman et al. 2003; Pellow, 2005, 2007). The fight against the disproportionate incidence of pollution in areas predominantly black, Hispanic, or indigenous was also seen as a fight against "environmental racism", a concept that in the EJOs' language means to treat badly other people in pollution or resource extraction injustices on grounds of membership of particular ethnic groups, social class or caste.

In EJ conflicts, the disproportionate incidence of morbidity or mortality sometimes cannot be proved from official statistics because of the lack of doctors or hospitals in the areas concerned. Hence the rise of so-called "popular epidemiology" (Brown 1992, 1997), a concept of relevance in many struggles inside and outside the United States - think for instance of the attempts by the plaintiffs in the Chevron-Texaco case in Ecuador to gather information in the 2000s related to the 1970s and 1980s of the incidence of cancer in the Sucumbios region of the Amazon by resorting to the memories of the local populations, proving that such memories concentrated around areas with wells and pools for the disposal of extraction water (Martin Beristain et al. 2009). Think of the long battle to have valid figures on the victims of the Bhopal accident. Popular epidemiology implies that "lay" knowledge of pollution illnesses is not less valid than official knowledge. It is a concept that fits into the "post-normal science" theory (Funtowicz and Ravetz 1993), "street science" (Corburn 2005) and the notion of "activists mobilizing science" (Conde 2015).

Reflecting the specific environmental challenges and distributional inequities of the global South, some EJOs adopted the term "environmentalism of the poor" which as explained above, is very close to the notion of EJ born in the US but applies less to urban than to rural peoples in the global South, like the Navajo in New Mexico who suffered from uranium mining. Academics started to use this term in 1988-89 (drawing on research on 
India and Latin America). Similar words had been used by Anil Agarwal, the founder of the CSE in Delhi and editor of the First Citizens' Report on the State of India's Environment. His successor, Sunita Narain, often uses this term to refer to the struggles in India against dams, deforestation, mining projects and nuclear power stations (Narain 2008). Recently Shrivastava and Kothari (2012) have compiled many socio-environmental struggles and successes while putting forward a proposal for a radical ecology democracy.

The "environmentalism of the poor" (and of the indigenous) is a concept opposed to the influential "post-materialist" interpretation of environmentalism (and other new social movements) by Ronald Inglehart (Inglehart 1995). It does not envision environmental preservation as a luxury good, contrary to what Inglehart did. It is also contrary to Ulrich Beck's view of environmental risks as being impartial to social class (as might have been the case for a nuclear accident such as Chernobyl but which is not true in general) (Beck 1992). The "environmentalism of the poor" is expressed by the poor and indigenous in place-based struggles for their own material livelihoods. In most ecological distribution conflicts, the poor are more often than not on the side of preservation of nature against business firms and the State. This behavior is consistent with their interests and their values, including the defense of indigenous territorial rights and claims regarding the sacredness of particular elements of nature (a mountain, a forest, a river or lake, or even a tree). It follows that those affected will be motivated to act provided that there is a sufficient degree of democracy and they are not suffocated by fear or are not violently repressed. In the EJAtlas we have collected about 2100 cases of socio-environmental conflict by May 2017. In about $12 \%$ one of the outcomes is (one or more) "deaths" of environmental defenders.

One of the primary environmental challenges faced by populations of the global South stems from an economic system that produces "ecologically unequal trade", an academic concept (Bunker 1985; Hornborg 1998, 2005; Hornborg et al. 2007) mentioned earlier. One 
form of such unequal trade has been called biopiracy by Pat Mooney of RAFI in 1993 and Shiva (1997). Biopiracy denotes the appropriation of genetic resources (in medicinal or agricultural plants) without any recognition of the original knowledge and "property rights" of indigenous peoples. The word "biopiracy" has been used in many complaints by EJOs. Even State authorities in Brazil and India have started to use this term. Many academics writers and doctoral students also use it (Robinson 2010).

There are a number of other EJO concepts and policies that stem from the conflicts over biomass. The many complaints against tree plantations grown for wood or paper pulp, depriving local people of land and water, led to the slogan and movement "Plantations are not forests" twenty years ago. In Brazil, "green deserts" was the spontaneous, bottom up name for eucalyptus plantations in some regions, which were opposed by local peasants and indigenous peoples. This was certainly a form of enclosure of commons. The driving force was the export of paper pulp and cellulose.

The related concept "food sovereignty" was introduced in the early 1990s by Via Campesina, an international movement of farmers, peasants, and landless workers. Food sovereignty means the right of rural people (including women in particular) to grow their own food for themselves and for local markets, against corporate agriculture, particularly against agrofuel monocultures and tree plantations (Schutter 2012; GRAIN 2005). A small organization called GRAIN introduced in 2008 the term "land-grabbing" to showcase the new wave of land acquisitions- ${ }^{-}$often by force- in Southern countries, for new plantations for exports. The term was then taken up by the Journal of Peasant Studies in special issues, including a Forum on Global Land Grabbing (2011; vol. 38 issue 2).

A term originating from the EJOs that has been very successful in the fights against ecologically unequal trade and for identifying those responsible for climate change is that of the "ecological debt" (Robleto and Marcelo 1992; Borrero 1994). There was an alternative 
treaty in Rio de Janeiro in 1992 (in contrast to United Nations Conference on Environment and Development (UNCED), popularly known as Earth Summit), on the ecological debt from North to South. Acción Ecológica of Ecuador took the term and the struggle up in 1997, with several publications which included a definition and many examples. The ecological debt arises from the plundering away of resources and also from the occupation of disproportionate environmental space by the rich countries (to deposit an excessive amount of carbon dioxide in the oceans and the atmosphere, which belong to all humans equally). Some governments from countries of the South have deployed the concept of "ecological debt" (or one part of it, the "climate debt") in international negotiations on climate change (Bond 2010). In the 2009 Copenhagen Conference of the Parties (COP), perhaps over 30 heads of government or ministers talked about the ecological debt awakening the fury of the US Ambassador, Todd Stern (Reuters 2009). The origin of the concept and many of the theoretical developments are mainly due to Latin American EJOs (Martinez-Alier, 2002) and to some extent also to the international Friends of the Earth (FoE) and Jubilee South . Academics joined in later doing some calculations (Paredis et al. 2008; Srinivasan et al. 2010; Roberts and Parks 2009; Warlenius et al. 2015). Pope Francis' encyclical Laudato si of June 2015 devotes paragraphs 51 and 52 to the ecological debt from North to South and to the environmental liabilities of transnational companies.

The position of the rich countries, in contrast, denies liability for climate change. Todd Stern, the US climate envoy, repeated in Paris in 2015 what he had said in Copenhagen in 2009: the US had long acknowledged there was a need to support countries acutely vulnerable to climate change impacts, but there was "one thing that we do not accept and will not accept in this agreement and that is the notion that there should be liability and compensation for loss and damage. That is a line that we can't cross". He was supported by Miguel Arias Cañete, EU climate commissioner, who said there was now a "growing 
understanding" that loss and damage provisions would be included in the Paris Agreement, as long as they did not expose wealthy countries to new claims for compensation. Therefore, the Paris agreement denies liability and offers no recognition of an ecological debt (Financial Times, 6 Dec. 2015).

Unsurprisingly, it was also EJOs that had introduced and developed the related concept of "climate justice". An influential role in its introduction and dissemination was played by the CSE (Delhi) booklet of 1991, Global Warming in an unequal world: A Case of Environmental Colonialism, authored by Anil Agarwal and Sunita Narain pointing out that there were subsistence carbon dioxide emissions vs. luxury carbon dioxide emissions and it is important to differentiate the two (Shue 1994, 1999). Subsequently, in the late 1990s came the Jubilee campaign against Northern financial bullying of the South, comparing the large ecological debt from North to South to the financial debt from South to North (Simms et al. 1999; Simms 2005). The concept of climate debt was supported by the World Council of Churches, the Third World Network, Action Aid, and Christian Aid.

A 2000 event in The Hague sponsored by the New York group CorpWatch was the first known conference based on this term (Bond, 2011, 2013). CorpWatch in a document in November 1999 stated that

Climate Justice means, first of all, removing the causes of global warming and allowing the Earth to continue to nourish our lives and those of all living beings. This entails radically reducing emissions of carbon dioxide and other greenhouse gases. Climate Justice means opposing destruction wreaked by the Greenhouse Gangsters at every step of the production and distribution process - from a moratorium on new oil exploration, to stopping the poisoning of communities by refinery emissions-from drastic domestic reductions in auto emissions, to the promotion of efficient and effective public transportation (Bruno et al. 1999).

Four years later, the Durban Group for Climate Justice was launched. It made itself well-known by its campaigns against fake Clean Development Mechanism projects. 
The concept of water justice is associated with a university professor, Rutgerd Boelens (Wageningen University; Boelens et al. 2011) but he has been working so closely with activists for many years that he himself would no doubt like to see water justice or hydric justice as concept of the EJOs themselves. Their favorite slogans are "water runs towards power" and "water runs towards money" unless stopped by civil society movements. The World Commission on Dams (WCD) was a civil society initiative that reported its conclusions in 2000 (WCD 2000). Among its members were representatives of business and of the World Bank, and also of conservationist organizations. It arose because of the strength of resistance movements against dams, the most visible at the time being the Narmada Bachao Andolan in India where Medha Patkar's campaigns had been most influential (McCully 1996). The WCD's conclusions went directly against the unidimensional costbenefit analysis procedures for deciding on dam building. The WCD report recommendations have not been implemented. Anti-dam movements continue to denounce water enclosures along with forced acquisition of land, diversion of rivers, and dispossession and displacement of rural and indigenous communities inhabiting territories rich in biodiversity and water sources (Rodriguez-Labajos and Martinez-Alier, 2015).They include the Brazilian MAB (Movement of People Affected by Dams) and the MAPDER network in Mexico. The EJAtlas provides many cases on conflicts on water where several valuation languages are deployed.

Meanwhile, another new term has been appearing with greater regularity in recent years in EJ struggles: "the commons movement". This looks at the commons as a crucial sector of the economy which must be defended to preserve decommodified access to food, water, forests, and clean air (Di Chiro 1998). Influenced by Karl Polanyi, the movement fights against old and new enclosures. Since the late 1980s, as a reaction against Garrett Hardin's misnamed "tragedy of the commons", authors like John Kurien defended in India and elsewhere small scale fisheries against large scale industry, using the term "modern 
enclosures" or "the tragedy of enclosures" (Martinez-Alier 1991). In municipal water management, paradigmatic movements against privatization of urban water services as in Cochabamba, Bolivia, are sources of inspiration for the defense of the commons in general (including access to information) and also for the defense of the human right to water.

Proposals to "leave oil in the soil", also in defense of the commons, were first put forward in 1997. We now call them Yasunizing or Ogonizing and they come from Acción Ecológica Ecuador, ERA of Nigeria, and the Oilwatch network founded in 1995. Such proposals apply also to tar sands, to coal ("leave coal in the hole") and shale gas. In the form of moratoria to extraction projects, they are applicable in particular for areas of great biodiversity value and where human rights are threatened. To such local reasons, climate change reasons are added, based on the thesis that there are "unburnable fuels" if we want to stop increasing the concentration of carbon dioxide in the atmosphere (Temper et al. 2013). A new major figure in the climate justice movement, Naomi Klein (2014), became acutely aware of Ogonization and Yasunization movements - she calls them Blockadia, a name used by activists in Canada and the US (sometimes indigenous) stopping the contruction of oil and gas pipelines. One case in Sompeta (Andhra Pradesh) became well known because the connection between local complaints and climate change (https://ejatlas.org/conflict/sompetapower-plant). Community members, especially fishermen and farmers, were opposed to the construction of a coal fired power plant since it would destroy their entire livelihoods. The proposed construction site was on an expanse of wetlands and the villagers of Sompeta used this land to sustain their fisheries and farmlands.

Also in the field of energy policy, the civil society movements against nuclear energy since the 1970s gave rise to their own concepts. One of them, in Germany, was Energiewende (born in Wyhl, https://ejatlas.org/conflict/whyl-in-germany) which is now used in official public policy. Germans use sometimes a parallel term, Wachstumwende (growth turnaround), 
to translate the French décroissance or English "degrowth," a movement in some Northern countries born in alternative urban or rural movements ( Chatterton and Pickerell 2010) that disengage mentally and practically from the growth economy. In Germany, post-Wachstum is also used. The degrowth movement might support EJ (Healy et al, 2012), for instance by asking for resource caps, meaning a policy to reduce extraction of materials. Resource caps have been discussed since the 1990s (Spangenberg 1995) in terms of calculations of "fair shares" in the use of limited resources and limited environmental space. Degrowth is also very sympathetic to claims of an ecological debt from the South. This“degrowth movement has different sources (Martinez-Alier et al. 2010; Demaria et al. 2013; D’Alisa et al. 2014) including the proto-ecological economist Georgescu-Roegen (1971) but also the "postdevelopment" movement of the 1980s of Ashish Nandy, Shiv Visvanathan, Gustavo Esteva, Arturo Escobar, Wolfgang Sachs, Serge Latouche, and Vandana Shiva (Sachs 1992). An alliance between the degrowth (or steady-state economy or post Wachstum) movements in the North and the global EJ movement was proposed by Martinez-Alier (2012) while in South America there are calls for a "post-extractivist" economy (by Eduardo Gudynas, Alberto Acosta, Maristella Svampa) leading to buen vivir instead of economic growth.

Other new concepts that are growing among the EJOs are "energy sovereignty", “sacrifice zones" (Lerner, 2010), "ecocide" (Zierler 2011) and the call for an international environmental crimes tribunal (complementary to demands for civil liabilities). Refusing to participate in the game of corporate social responsibility, the EJOs have asked for corporate accountability (Broad and Cavanagh 1999). The new provision on the "rights of nature" (introduced in Ecuador's Constitution 2008, article 71, after an original idea from Accion Ecologica) is also popular among the EJOs that see themselves as fighting against crimes against humanity and crimes against nature. 
The movement in Southern Italy denounces the eco-mafia and campaigns against waste dumping, complaining about "biocide” (Armiero and D'Alisa 2012). There must be many other national or regional terms of EJ that we could discover through the EJAtlas. For instance, in India conflicts on sand and gravel mining from rivers or beaches are particularly acute (with people getting killed in different states), and the new label "sand mafias" was given to this phenomenon. Similarly in China, in the complaints against pollution not only in urban areas but also in rural areas, the term "cancer villages" began to be used in the last ten years or so (Lora-Wainright 2013). Researchers registering such complaints in China appeal to the notion of "popular epidemiology" born in the 1980s in the United States. According to Lora-Wainright (2017) there is feeling of powerlessness among protestors against pollution in the Chinese villages she studied. In Argentina, there is a long-delayed but growing movement against glyphosate (used for transgenic soy cultivation introduced by Monsanto), under the name paremos de fumigar ("stop fumigating"). Laudato si (para. 135) mentions the danger to people living near fumigated fields. In Brazil one term from local transport conflicts is justiça nos trilhos, "justice in the railways" against the loss of life in accidents caused by massive iron ore transport to the export harbours (Porto et al. 2013).

For the EJ movement of the 1980s, with urban roots, a good environment as defined by the 1991 People of Color Environmental Leadership conference in Washington DC was a safe, non-polluted place for living and making a living — environment is where we "live, work, and play". Most of the world population is now urban. Inside cities, there are inter-connected movements introducing new concepts for a less unsustainable economy, such as "food justice", "transit justice", cyclist and pedestrian rights (cyclists" "critical mass" movements in many cities) (Carlsson 2008), and fights against gentrification. Such urban movements give a political meaning to squatting (Cattaneo 2011), they remake places for groups in danger of being "dis-placed", re-assert traditional or new practices of land use, urban food prodution 
and water harvesting, and try to protect territory from contamination, land grabbing and real estate speculation (Gottlieb 2009; Gottlieb and Joshi 2010; Anguelovski 2014).

New terms and new cultural manifestations of the global environmental justice movement appear from time to time. Thus, in parallel to "land grabbing", the movement in defense of fisherfolk has proposed the slogan "ocean grabbing", to cast new light on processes of enclosures negatively affecting communities whose cultural identity and livelihoods depend on their involvement in small-scale fishing. Ocean grabbing thus means the capturing of control by powerful economic actors of crucial decision-making around fisheries, their main concern being making profits by gaining control of both the fisheries' resources and the benefits of their use. https://www.tni.org/en/collection/ocean-grabbing

In India in 2017, the Carnatic song by T.K. Krishna complaining about the destruction of Ennore Creek north of Chennai by coal fired power plants and other polluting industries became a hit. The song condenses into a few phrases a research paper by environmentalist Nityanand Jayaraman, insisting that the meaning of the word Poromboke in Tamil is "the commons". Mangroves and beaches are commons, and are being destroyed: Poromboke ennaku illai, poromboke unnaku illai (Poromboke is not for me, it is not for you). Poromboke ooruike, poromboke bhoomikku (Poromboke is for the city, it is for the Earth).

\section{Conclusion}

A well known expert in agrarian studies who reviewed my boon The Environmentalism of the Poor (Bernstein, 2005) wrote that it merely provided a series of "vignettes" of environmental conflicts, not weighty enough to support the thesis that there is a rural and urban global movement for environmental justice. Now we have the EJAtlas, and more evidence also from other sources to show that such a global movement exists although it (fortunately?) lacks a 
“central committee" or "politbureau”. EJ networks spread out across borders (Keck and Sikkin, 1998; Bandy and Smith, 2005).

Environmental conflicts are related to the changing and growing social metabolism of industrial economies (Fischer-Kowalski and Haberl 1997, 2007, 2015; Steinberger et al. 2010; Martinez-Alier, Temper, and Demaria 2014). Energy cannot be recycled. Therefore, the energy from the fossil fuels can be used only once, and new supplies of coal, oil, and gas must be obtained from the "commodity extraction frontiers" (Moore 2000). Similarly, materials can be recycled only in part, and therefore, even an economy that would not grow would need fresh supplies of iron ore, bauxite, copper, and paper pulp. The economy is not circular; it is entropic (Haas et al, 2015). Meanwhile, renewable resources such as aquifers, timber, and fisheries are overexploited, the fertility of the soil is jeopardized and biodiversity is depleted. Thus, the changing social metabolism of industrial economies (incuding the excessive production of carbon dioxide) gives rise to conflicts on resource extraction, transport, and waste disposal. Such ecological distribution conflicts sometimes overlap with other social conflicts on class, ethnicity or indigenous identity, gender, caste or territorial rights. The gains and losses of the use of the environment are often unjustly distributed not only with regard to other species or future generations of humans but also among humans living today. There are many local movements expressing their grievances over such environmental injustices. Sometimes there are complaints against international ecologicaly and economic unequal exchange. Sometimes, in large countries such as India, there are complaints against internal colonialism.

Several groups have been producing inventories of ecological distribution conflicts (by country, continent or theme), such as OCMAL in Latin America on mining conflicts, or Fiocruz in Brazil on all kinds of environmental conflicts (Porto, 2013). Our own contribution 
has been to build up the EJAtlas at ICTA-UAB (Temper et al, 2015, Martinez-Alier et al 2016) with many outside collaborators.

Social mobilizations over resource extraction, environmental degradation, or waste disposal are not only about the distribution of environmental benefits and costs (expressed in monetary or non-monetary valuation languages); they are also about participation in decisionmaking and recognition of group identities. All such issues appear very regularly in the cases collected in the EJAtlas (Schlosberg 2007; Walker 2012; Sikor and Newell 2014). EJ research encompasses issues of exclusion (Agarwal 2001) but also of the potential new leadership of environmental movements by different social actors, e.g. in the environmentalism of the poor as in EJ movements in general, it is crucial to recognize the contribution women make in poor communities both rural and urban (Agarwal 1992). Since the 1980s, EJOs and their networks have provided definitions and analyses of a wide array of concepts and slogans related to environmental inequities, and explored the connections and articulations between them. The protests against the World Trade Organization in Seattle in 1999 and at the World Social Forums of the 2000s certainly pushed forward the globalization of EJ (for instance, the Ecological Debt was featured in the alternative meetings to the WB and IMF assembly in Prague in 2000). There were earlier underpinnings in the alternative "treaties" signed at Rio de Janeiro in 1992 and in the 1991 People of Color Environmental Justice Leadership Summit. EJ spread through organizations like Friend of the Earth, which, while born in California as a "white" conservationist movement, brought in EJOs which existed since the 1980s like CENSAT in Colombia and WALHI in Indonesia. Other environmental organizations such as the CSE in Delhi and Acción Ecológica in Ecuador linked the idea of environmentalism of the poor with wider notions of EJ and climate justice (FOEI, 2005). 
With these activist and social movement roots, the concepts of EJ were then taken up in academic research in political ecology studying Southern countries. Going beyond case studies, researchers now generate statistics on ecological distribution conflicts (Özkaynak and Rodriguez-Labajos 2012; Latorre et al 2015; Martinez-Alier et al. 2016) made possible by the EJAtlas and similar inventories. The social sustainability sciences (human ecology, ecological economics, political ecology, environmental law, environmental sociology, ecological anthropology and ethno-ecology, environmental history, environmental politics, urban ecology, agroecology, industrial ecology) have an academic origin, with international societies, academic journals and handbooks, and professorships that go under such names. Many concepts and theories have been produced in these booming fields of science in the last 30 years. There are also grassroots concepts for sustainability introduced by EJOs which have been discussed here and which are also objects of academic research. Such concepts support the global EJ movement, at the same time they also support local rural and urban movements protecting territory and defending place-based interests and values (Escobar 2008;

Anguelovski and Martinez-Alier 2014).

\section{REFERENCES}

Agarwal A and Narain S 1991 Global warming in an unequal world: a case of environmental colonialism, New Delhi, Centre for Science and Environment

Agarwal, B. 2001. Participatory exclusions, community forests and gender: An analysis for South Asia and a conceptual framework. World Development 29 (10): 1623-48.

Agyeman, J., R. Bullard, and B. Evans, eds. 2003. Just sustainabilities: Development in an unequal world. Cambridge, MA: MIT Press.Anguelovski, I. (2014). Neighborhood as Refuge: Environmental Justice, Community Reconstruction, and Place-remaking in the City (Cambridge, MA: MIT Press).

Anguelovski, I. and J. Martinez-Alier. (2014). The 'Environmentalism of the Poor' Revisited: Territory and Place in Disconnected Global Struggles. Ecol. Econ. 102: 167-76.

Armiero, M. and D'Alisa, G. (2012)., "Rights of Resistance: The Garbage Struggles for Environmental Justice in Campania, Italy." Capitalism, Nature, Socialism 23(4): 52-68. 
Bandy, J. and J. Smith. 2005. Coalitions across borders: Transnational protest and the neoliberal order. Lanham, MD and Oxford: Rowman and Littlefield.

Barca, S. (2012). "On Working-class Environmentalism. An Historical and Transnational Overview." Interface. A Journal for and about Social Movements 4(2): 61-80.

Beck, U. (1992). Risk Society. Towards a New Modernity (London: Sage).

Bernstein, H. 2005. The Environmentalism of the Poor. A Study of Ecological Conflicts and Valuation (book review), J. of Agrarian Change, 5(3):429-436.

Blaikie, P. and H. Brookfield. 1987. Land degradation and society.. London: Methuen.

Blanco, H. (1991). El ecologismo de los pobres, La República. April 6, 1991. http://hugoblancogaldos.blogspot.com.es/2008/12/el-ecologismo-de-los-pobres.html

Boelens, R., Cremers, L., and Zwarteveen, M., eds. (2011), Justicia Hídrica. Acumulación, conflicto y acción social (Lima: Instituto de Estudios Peruanos).

Bond, P. (2013). “Climate Justice.” In Critical Environmental Politics, edited by C. Death (London: Routledge), p. 133-145.

Bond, P. 2011. Carbon Capital's trial, the Kyoto protocol's demise, and openings for climate justice. Capitalism Nature Socialism 22 (4): 2-17.

Borrero, J. M. (1994). La Deuda Ecológica. Testimonio de una reflexión (Cali: FIPMA).

Broad, R. and Cavanagh, J. (1999).The Corporate Accountability Movement: Lessons and Opportunities. The Fletscher Forum of World Affairs 23(2): 151-69.

Brown P 1987 Popular Epidemiology: Community Response to Toxic Waste-Induced Disease in Woburn, Massachusetts Science, Technology, \& Human Values 12 (3/4): 78-85.

Brown, P. (1992). "Popular Epidemiology and Toxic Waste Contamination: Lay and Professional Ways of Knowing." Journal of Health and Social Behavior 33: 267-81.

Brown, P. (1997). "Popular Epidemiology Revisited.” Current Sociology 45: 137-56.

Bruno, K., Karliner, J., and Brotsky, C. (1999)., "Greenhouse Gangsters vs. Climate Justice." CorpWatch. http://www.corpwatch.org/article.php?id=1048

Bryant B, Mohai P 1992 Race and the Incidence of Environmental Hazards: A Time for Discourse. Westview Press, Boulder CO

Bullard R D 1993 Confronting Environmental Racism: Voices from the Grassroots South End Press, Boston

Bullard R D 1990 Dumping In Dixie: Race, Class, and Environmental Quality Westview Press, Boulder CO

Bunker, S. 1984. Modes of extraction, unequal exchange, and the progressive underdevelopment of an extreme periphery. The Brazilian Amazon. American Journal of Sociology 89: 1017-1064.

Bunker, S. (1985). Underdeveloping the Amazon. Extraction, Unequal Exchange, and the Failure of the Modern State (Chicago: University of Chicago Press).

Camacho, D. 1998. The environmental justice movement. In Environmental injustices, political struggles: Race, class, and the environment. D. Camacho, ed. Durham, NC: Duke Univ. Press.

Carlsson, C. (2008). Nowtopia: How Pirate Programmers, Outlaw Bicyclists and Vacant-lot Gardeners Are Inventing the Future Today (Oakland, CA: AK Press).

Carmin, J.A. and J. Ageyman, eds. 2010. Environmental inequalities beyond borders: Local perspectives on global injustices. Cambridge, MA: MIT Press.

Carrere, R. and L. Lohman. 1996. Pulping the South. Industrial tree plantation and the world paper economy. London: Zed Books. 
Cattaneo, C. (2011). "The Money-free Life of Spanish Squatters.”, chapter 10 in Life Without Money, edited by Anitra Nelson (London: Pluto Press).

Chatterton, P. and Pickerell, J. (2010). Everyday Activism and Transitions Towards Post-capitalist Worlds. Transactions of the Institute of British Geographers 35: 475-90

Conde, M., (2014), Activism Mobilising Science. Ecological Economics, 105, pp. 67-77, DOI 10.1016/j.ecolecon.2014.05.012

Corburn J. (2005). Street Science: Community Knowledge and Environmental Health Justice (Cambridge, MA: MIT Press).

D’Alisa, G. Demaria F. Kallis, G. eds, 2014 Degrowth: a vocabulary for a new era, Routledge, London.

Della Porta D and Rucht D 2002 The Dynamics of Environmental Campaigns. Mobilization: An International Journal 7(1) 1-14

Demaria, F. 2010. Shipbreaking at Alang-Sosiya (India): An ecological distribution conflict. Ecological Economics 70 (2): 250-260.

Demaria, F., Schneider, F., Sekulova, F., and Martinez-Alier, J. (2013). "What is Degrowth? From an Activist Slogan to a Social Movement." Environmental Values 22(2): 191-215.

Di Chiro, G. (1998). "Nature as Community. The Convergence of Social and Environmental Justice." In Privatizing Nature: Political struggles for the Global Commons, edited by M. Goldman (London: Pluto).

Escobar A 2008 Territories of Difference: Place, Movements, Life, Redes. Durham, Duke UP,

Fischer-Kowalski, M. and Haberl, H. (1997). "Tons, Joules and Money: Modes of Production and their Sustainability Problems." Society and Natural Resources 10(1): 61-85.

Fischer-Kowalski F Haberl H eds 2007 Socioecological Transitions and Global Change: Trajectories of Social Metabolism and Land Use. Edward Elgar Publishing Limited, Cheltenham

Fischer-Kowalski F Haberl H, 2015, Social metabolism: a metrics for biophysical growth and degrowth, chapter 5 in J. Martinez-Alier, R. Muradian, eds. Handbook of Ecological Economics, Edward Elgar, Cheltenham.

Friends of the Earth International (FOEI). (2005). Climate Debt. Making Historical Responsibility Part of the Solution. http://www.foei.org/en/resources/publications/climate-justiceand-energy/20002007/climatedebt.pdf/at_download/file

Funtowicz S O and Ravetz J R 1993 Science for the Post-Normal Age Futures 25 735-755.

Georgescu-Roegen, N. 1971. The entropy law and the economic process. Cambridge, MA: Harvard Univ. Press.

Gerber J F 2011 Conflicts over industrial tree plantations in the South: Who, how and why? Global Environmental Change 21(1): 165-176

Gerber, J. F. 2016, The Legacy of K. William Kapp, Development and Change, DOI: $10.1111 /$ dech.12238

Gottlieb R. (2005). Forcing the Spring: The Transformation of the American Environmental Movement (Washington, DC: Island Press).

Gottlieb R. (2009). Where We Live, Work, Play . . . and Eat: Expanding the Environmental Justice Agenda. Environmental Justice 2: 7-8.

Gottlieb, R. and Joshi, A. (2010). Food Justice (Cambridge, MA: MIT Press). 
GRAIN. (2005). "Food Sovereignty: Turning the Global Food System Upside Down." Seedling. http://www.grain.org/article/entries/491-food-sovereignty-turning-the-global-food-system-upsidedown (accessed March 28, 2013).

Guha R and Martinez-Alier J 1997 Varieties of environmentalism. Essays North and South Earthscan, London.

Guha, R., Martinez-Alier, J., 1999. Political ecology, the environmentalism of the poor and the global movement for environmental justice. Kurswechsel 3, 27-40.

Haas, W., Krausmann, F.,Wiedenhofer D., Heinz,M. 2015 How Circular is the Global Economy?: An Assessment of Material Flows, Waste Production, and Recycling in the European Union and the World in 2005, J. of Industrial Ecology, DOI: 10.1111/jiec.12244

Healy, H., Martinez-Alier, J., Temper, L. Walter, M., Gerber J.F.eds 2012. Ecological economics from the ground up, Routledge, London.

Hornborg A 1998 Towards an Ecological Theory of Unequal Exchange. Articulating World System Theory and Ecological Economics. Ecol. Econ. 25 127-136.

Hornborg A 2005 Footprints in the cotton fields: The Industrial Revolution as time-space appropriation and environmental load displacement Ecological Economics 59 74-81.

Hornborg, A., McNeill, J. R., and Martinez-Alier, J., eds. (2007). Rethinking Environmental History, World-system History and Global Environmental Change (Lanham MD: Atamira Press).

Inglehart, R. 1995, Public Support for Environmental Protection: Objective Problems and Subjective Values in 43 Societies, PS: Political Science and Politics, 28(1): 57-72.

Kapp, K.W. 1950. Social costs of business enterprise . London: Asia Publishing House.

Keck, M., Sikkin, K. 1998. Activists beyond borders: advocacy networks in international politics, Cornell U.P., Ithaca, N.Y.

Krausmann, F., S. Gingrich, N. Eisenmenger, K.H. Erb, H. Haberl and M. Fischer-Kowalski. 2009. Growth in global materials use, GDP and population during the 20th century. Ecological Economics 68 (10): 2696-2705.

Latorre, S., Farrell, K., Martinez-Alier, J. (2015), "The commodification of nature and socioenvironmental resistance in Ecuador: An inventory of accumulation by dispossession cases, 19802013”. Ecological Economics.116: 58-69.

Lerner, S. 2010 Sacrifice Zones. The Front Lines of Toxic Chemical Exposure in the United States (preface by Phil Brown), MIT Press, Cambridge MA.

Lora-Wainright, Anna. (2013). Fighting for Breath: Living Morally and Dying of Cancer in a Chinese Village (Honolulu: University of Hawai Press).

Lora-Wainright, Anna (2017). Resigned Activism. Living with Pollution in Rural China (Cambridge: MIT Press).

Martin Beristain, C., Paez, D., and Fernandez, I. (2009)., Las palabras de la selva: Estudio psicosocial del impacto de las explotaciones petroleras de Texaco en las comunidades amazónicas de Ecuador (Bilbao: Hegoa).

Martinez-Alier, J. (1991)., "Ecology and the Poor: A Neglected Dimension of Latin American History." J. of Latin American Studies 23(3): 621-39.

Martinez-Alier, J. (1995), 'Distributional issues in ecological economics', Review of Social Economy, 53, 511-28.

Martinez-Alier J., O'Connor, M. 1996 Economic and ecological distribution conflicts, in R. Costanza, O. Segura and J. Martinez-Alier eds, Getting down to earth. Practical applications of ecological economics. Island Press, Washington DC. 
Martinez-Alier, J., Pascual, U., Vivien, F., and Zaccai, E. (2010). "Sustainable De-growth: Mapping the Context, Criticisms and Future Prospects of an Emergent Paradigm." Ecological Economics 69(9): $1741-7$.

Martinez-Alier, J., Temper, L., and Demaria, F. (2014). "Social Metabolism and Environmental Conflicts in India." Indialogs 1: 51-83.

Martinez-Alier, J., Anguelovski, I., Bond, P., Del Bene, D., Demaria, F., Gerber, J.-F., Greyl, L., Haas, W., Healy, H., Marín-Burgos, V., Ojo, G., Firpo Porto, M., Rijnhout, L., Rodríguez-Labajos, B., Spangenberg, J., Temper, L., Warlenius, R., and Yánez, I. (2014). "Between Activism and Science: Grassroots Concepts for Sustainability Coined by Environmental Justice Organizations." Journal of Political Ecology 21: 19-60.

Martinez-Alier, J., Temper, L., Del Bene, D., Scheidel, A. 2016, Is there a global movement for environmental justice? Journal of Peasant Studies, 43(3): 731-755

Martinez-Alier, J. 2002. The environmentalism of the poor: A study of ecological conflicts and valuation. Cheltenham: Edward Elgar.

Martinez-Alier, J. 2012. Environmental Justice and Economic Degrowth: an alliance between two movements. Capitalism, Nature, Socialism, 23(1): 51-73.

Martinez-Alier, J. 1995 The Environment as a Luxury Good or "Too Poor to Be Green", Ecol. Econ.,13: 1-10.

Martinez-Alier J 1997 Environmental Justice (Local and Global) Capitalism, Nature, Socialism, 8(1) 91-107

Martinez-Alier, J., G. Munda, and J. O'Neill. 1998. Weak comparability of values as a foundation for ecological economics. Ecol. Econ.. 26 (3): 277-286.

McCully, P. 1996. Silenced rivers: The ecology and politics of large dams. London: Zed Books.

Moore, J.W. 2000. Sugar and the expansion of the early modern world-economy: Commodity frontiers, ecological transformation, and industrialization. Review: A Journal of the Fernand Braudel Center, 23 (3): 409-433.

Muradian, R., Martinez-Alier, J., Walter, M. (2012). "Hegemonic Transitions and Global Shifts in Social Metabolism: Implications for Resource-rich Countries." Global Environmental Change 22: 559-67.

Narain, S. (2008). "Learn to Walk Lightly.” Business Standard (August 1, 2008).

Özkaynak, B., Aydın, C.I., Ertör-Akyazı, P. \& Ertör, I. 2015a The Gezi Park Resistance from an Environmental Justice and Social Metabolism Perspective, Capitalism, Nature, Socialism, 26(1): 96114.

Özkaynak, B., Rodriguez-Labajos, B., Aydın, C.I., Yanez,I., Garibay, C., 2015b Towards environmental justice success in mining conflicts: An empirical investigation, EJOLT Report 14, 96 p.

Peet, R. and M. Watts, eds. 1996. Liberation ecologies: Environment, development and social movements. London: Routledge.

Pellow, D.N. 2007. Resisting global toxics: Transnational movements for environmental justice. Cambridge, MA: MIT Press.

Pellow, D.N. and R. J. Brulle. 2005. Power, justice, and the environment: A critical appraisal of the environmental justice movement. Cambridge, MA: MIT Press.

Perez-Rincon, M.A. 2006. Colombian international trade from a physical perspective: Towards an ecological Prebisch thesis. Ecol. Economics, 59 (4): 519-529.

Porto de Souza, M. F., Pacheco, T., Leroy, J. P.,eds. (2013). Injustiça ambiental e saúde no Brasil. O mapa de conflitos (Rio de Janeiro: Fiocruz). 
Porto de Souza M.F. 2012 Movements and the Network of Environmental Justice in Brazil. Environmental Justice, 5(2) 100-104

Reuters. (2009). "U.S. Will Pay into Climate Fund, but Not Reparations: Todd Stern." http://www.reuters.com/article/2009/12/09/us-climate-copenhagen -sternidUSTRE5B82R220091209i

Roberts, J. T. and Parks, B. C. Parks (2009). "Ecologically Unequal Exchange, Ecological Debt, and Climate Justice. The History and Implications of Three Related Ideas for a New Social Movement." International Journal of Comparative Sociology 50: 385-409.

Robinson, D. F. (2010). Confronting Biopiracy. Challenges, Cases and International Debates (London: Earthscan), 191.

Robleto, M. L. and Marcelo, W. (1992). Deuda ecológica (Santiago de Chile: Instituto de Ecologia Politica).

Sachs, W. ed. (1992). The Development Dictionary: A Guide to Knowledge as Power (London: Zed Books).

Schlosberg, D. (2007). Defining Environmental Justice. Theories, Movements and Nature (Oxford: Oxford University Press).

Schlosberg D 2013 Theorizing Environmental Justice: The Expanding Sphere of a Discourse. Environmental Politics 22(1) 37-55

Schutter, O. de. (2012). From Food Security to Food Sovereignty. http://www.eesc.europa.eu/resources/docs/de-schutter.pdf (accessed March 28, 2013).

Shrivastava, A. and Kothari, A. (2012). Churning the Earth. The Making of Modern India (New Delhi: Penguin Viking).

Shiva, V. (1997). Biopiracy: The Plunder of Nature and Knowledge (Boston: South End).

Shue, H. (1994). "Subsistence Emissions, Luxury Emissions.” Law \& Policy 15: 39-59.

Shue, H. (1999). "Global Environment and International Inequality.” International Affairs 75: 53145.

Sikor, T. and Newell, P. (2014). "Globalizing Environmental Justice?" Geoforum 54: 151-7.

Simms, A. (2005). Ecological Debt. The Health of the Planet and the Wealth of Nations (London: Pluto Press).

Simms, A., Meyer, A., and Robins, N. (1999). Who Owes Who? Climate Change, Debt, Equity and Survival (London: Christian Aid). http://www.ecologicaldebt.org/Whoowes-Who/Who-owes-whoClimate-change-dept-equity-and-survival.html

Srinivasan, U. T., Carey, S. P., Hallstein, E., Higgins, P. A. T., Kerr, A. C., Koteen, L. E., Smith, A. B., Watson, R., Harte, J., and Norgaard, R. B. (2008). "The Debt of Nations and the Distribution of Ecological Impacts from Human Activities.” PNAS 5: 1768-73.

Steinberger, J. K., Krausmann, F., Eisenmenger, N. (2010). "Global Patterns of Materials Use: A Socioeconomic and Geophysical Analysis." Ecol. Econ. 69: 1148-58.

Tarrow, S., 2011, Power in Movement. Social Movements and Contentious Politics, Cambridge U.P., Cambridge ( $3^{\text {rd }}$ ed. $)$

Temper, L. and Martinez-Alier, J. 2013 The god of the mountain and Godavarman: Net Present Value, indigenous territorial rights and sacredness in a bauxite mining conflict in India. Ecological Economics, 96: 79-87

Temper, L., Yánez, I., Sharife, K., Ojo, G., Martinez-Alier, J., CANA, Combes, M., Cornelissen, K., Lerkelund, H., Louw, M., Martínez, E., Minnaar, J., Molina, P., Murcia, D., Oriola, T., Osuoka, A., Pérez, M. M., Roa Avendaño, T.,Urkidi, L., Valdés, M., Wadzah, N., and Wykes, S. (2013). Towards 
a Post-Oil Civilization: Yasunization and Other Initiatives to Leave Fossil Fuels in the Soil (EJOLT Report No. 6).

Temper, L., Del Bene, D., Martinez-Alier, J. 2015, Mapping the frontiers and front lines of global environmental justice: the EJAtlas, Journal of Political Ecology, 22: 255-278.

Tilly, L. and Tilly, C., eds. (1981). Class Conflict and Collective Action. (Beverly Hills: Sage).

Utting, P. (2008). "Social and Environmental Liabilities of Transnational Corporations. New Directions, Opportunities and Constraints." In Corporate Accountability and Sustainable Development, edited by J. Clapp and P. Utting (Delhi: Oxford University Press).

Walker, G. (2012). Environmental Justice: Concepts, Evidence and Politics (London: Routledge).

Warlenius, R. Pierce, G. Ramasar, V. 2015 Reversing the arrow of arrears: The concept of "ecological debt" and its value for environmental justice, Global Environmental Change, 30: 21-30.

Warr, B., R. Ayres, N. Eisenmenger, F. Krausmann, and H. Schandl. 2010. Energy use and economic development: A comparative analysis of useful work supply in Austria, Japan, the United Kingdom and the U.S.A. during 100 years of economic growth. Ecological Economics 69 (10): 1904-1917.

Zierler, D. (2011). The Invention of Ecocide: Agent Orange, Vietnam, and the Scientists Who Changed the Way We Think About the Environment (Athens: University of Georgia Press). 